\title{
Plastic Waste in Modern Era: Developing Plastic Waste Management for Sustainability
}

\author{
Fenty Puluhulawa* and Mohammad Rusdiyanto Puluhulawa \\ Faculty of Law, Gorontalo State University, 96128 Gorontalo, Indonesia
}

\begin{abstract}
Plastic waste is the primary concern for many countries worldwide. In Indonesia, the issue remains a problem that requires greater attention. Although several regulations have been implemented to reduce plastic waste, efforts and strategies are essential to maximizing the outcomes of the laws. Plastic waste, if it is not disposed of properly, brings adverse effects on health. By that, the regional government is urged to come up with policies to reduce plastic waste. This paper discussed: First, the issues of plastic and people's needs for plastic in today's era. Second, it explored the policies of the regional government in developing a waste management program to combat the problem. The data of this empirical juridical research came from the interview and focus group discussion involving several samples selected purposively.
\end{abstract}

\section{Introduction}

Modernization amidst society is assured to bring shifts in people's lifestyles and perspectives, leading to consumptive behavior and a culture of instant results. Population growth and high density have been a part of the changes in society, which leads to several positive effects, such as the development of technology, ease of access, and creative economy growth. Changes in the population, however, bring harm to the environment if one does not prepare for its negative impacts. This situation will, if precautions are not taken, lead to a decline in people's quality of life for the long-term. Plastic waste is among the global issue as it threatens environmental sustainability; unless a prior action has taken into account, things can get worse.

Pollution caused by plastic waste contaminates not only land but also the water environment. There are approximately 150 tons of plastic waste polluting the world's ocean [1]. Such an issue blames several factors, including poor management systems and disobedient. World Bank has reported that Indonesia places second after China in terms of the quantity of plastic waste missmanage with 3.22 million metric tons per year, with the percentage of the global miss-manage measuring at 10.1 . The amount of waste plastic miss-manage in China reaches 8.82 million metric tons per year, with the percentage of the worldwide miss-manage measuring at 27.7 [2]. It takes more than 20 years for a plastic waste to degrade in the soil; this process can even spend 100 years [2]. Plastic waste is also harmful to human health due to its dioxins content that is released if the plastic is burnt. Some plastics release harmful substances for the hormone system if it is buried [3]. In other words, although it has essential use in the modern era, plastic can bring negative impacts on health. This idea underpins the importance of waste management to minimize the use of plastic, specifically single-use plastic, and other harmful effects for humans.

As one of the provinces in Sulawesi, Gorontalo has its unique characteristics as it is located at the half part of Tomini bay. Tomini bay was used to be the resources for the kingdom surrounding the area. Waste issues have been one of the concerns that draw the attention of the government. The government of Gorontalo province, through Jakstrada program, has set the target for reducing plastic waste by $30 \%$ and the management of waste by $70 \%$ in 2025 [4]. The program will be implemented in regencies and cities within the province. Pohuwato regency is one of the selected objects, given its status as the largest regency $(35.84 \%)$ of the province; it holds potential as natural preservation sites, with its mangrove forests and biodiversity, including other sectors, e.g., fisheries and agriculture. A statistics in 2018 have reported 145,469 populations in the regency. Protecting the rights for a clean and healthy environment is essential for the people. That the location is in Tomini bay encourages the idea to develop the potential of the regency in the tourism sector. Tomini bay is about 43,100 $\mathrm{km} 2$, with its coastline measuring at $438.1 \mathrm{~km}$ [5].

Waste issues demand immediate solutions; some of the concerns involve a continuous increase in waste volume, poor self-awareness regarding personal and environmental hygiene (including coastal area), limited access for the government to reach several areas due to insufficient facilities and infrastructures. The focuses of this paper are twofold: First, it examines the issues of plastic and people's needs for plastic in today's era. Second, it explores the policies of the regional government in developing a waste management program

\footnotetext{
* Corresponding author: fentypuluhulawa@ung.ac.id
} 
to combat the problem.Use A4 paper size $(210 \times 297 \mathrm{~mm})$ and adjust the margins to those shown in Table 1. The final printed area will be $172 \times 252 \mathrm{~mm}$.

\section{Research method}

The data were collected from in-depth interviews and focus discussions with relevant stakeholders, government, village communities, coastal area communities, which were selected purposively. Interview results of this empirical juridical research were analyzed qualitatively in Pohuwato regency. Data analysis was carried out descriptively.

\section{Results and discussion}

\subsection{Plastic waste and the needs for plastics in modern era}

Efforts to restrict the use of plastic have been attempted through campaigns; this also functions to warn people about the negative impacts of environmental degradation. Despite being the center of attention, mitigations of the issue are not an easy task, especially at the empirical level, since it requires the participation of several stakeholders. Humans and natural resources are inseparable; for this reason, humans are responsible for preserving the environment since the resources are for the people to utilize [6]. Demands for speed has encouraged people to seek for something practical, such as single-use plastic, including plastic straw and plastic bag. Continuous use of such plastics will, in turn, trigger problems, such as seawater pollution (by which it clogs rivers and waterways, resulting in flooding) and an increase in plastic waste volume. The issues can get worsened since plastics are nonbiodegradable.

The significant impact of the deterioration of the environment on people's life has urged the nation to establish regulations within the nation's constitution. Environmental preservation has been stipulated in the 1945 Constitution of the Republic of Indonesia, in article $28 \mathrm{H}$, section (1), which discusses human rights: "Every person shall have the right to live in physical and spiritual prosperity, to have a home and to enjoy a good and healthy environment, and shall have the right to obtain medical care".

Although its focus is on the national economy and social welfare, article 33 , section (3) also corresponds with the issue of environmental preservation: "The land, the waters and the natural resources within shall be under the powers of the State and shall be used to the greatest benefit of the people".

Article $28 \mathrm{H}$, section (1), reveals that the rights for a clean and healthy environment are for all citizens to attain. This signifies that implementing environmental regulations is the key to create a clean and healthy environment [7]. Article 28H, section (1), is a part of the law concerning human rights within the constitution. It represents the acknowledgment of the rights for a quality environment. This idea is in line with the vice president
Justice Weeramantry [8]: "The protection of the environment is...a vital part of contemporary human rights doctrine, for it is sine qua non for numerous human rights such as the right to health and the right to life itself. It is scarcely necessary to elaborate on this, as damage to the environment can impair and undermine all the human rights spoken of in the Universal Declaration on Human Rights and in other human rights instruments."

On top of that, "In the sense of the former, poor environmental conditions can directly limit an individual's or a community's ability to enjoy a specific right" [9], which is guaranteed to them under law.

"A poor environment may affect an individual's or community's capacity to realize their human rights generally or impede a government's ability to protect the rights of its citizens" [9]. This blames the environmental factors that determine the level of rights fulfillment, and ecological degradation may be considered as a violation of human rights [9]. "Environmental factors may, therefore, influence or determine the level of rights fulfillment and environmental degradation can amount to a violation of those rights." "That human rights cannot be enjoyed in degraded environment" [9]. Quality environment is the prerequisite to the fulfillment of human rights. On that ground, environmental issues demand immediate solutions.

Modern lifestyle, especially in urban areas, has urged the culture of quick results. Such a shift starts to occur in rural areas. Instant gratification has been a part of the modern lifestyle. Nowadays, people prefer instant food, instant communication using message services through the internet, easily-accessible services, and single-use products that can be found anywhere. Examples of single-use products include plastic bags, plastic straws, paper and plastic glasses, foam food containers, and many more. These products are significant to fast-paced lives, but it has its costs if it is used long-term. Accumulation of garbage is an example of the negative impact of overusing single-use materials. Poor management of such wastes has long-term effects on humans and other living beings. Viewed as the whole process, it is regarded as a continuous and unbreakable cycle.

The impacts of nonbiodegradable plastics have initiated innovation, such as producing biodegradable plastics. This type of plastic is capable of being decomposed in soil. However, biodegradable plastics are not to be used long-term, as the only degradable material for most of these plastics is starch, meaning that it leaves microscopic plastic fragments. This idea resonates with reference [9], saying that: biodegradable plastics "are not biodegradable as a result of which they contribute very disruptive effects on agricultural development.

Further, it should be noticed that plastic waste "takes incredibly long time to break down and when they do, it is into powdery plastic dusts which contaminate all life forms including the soil and the water forever" [10].

Reference [11] emphasizes that "Plastic bags are made from polyethylene, a product of petroleum, which is a non-renewable natural resource but it is essential for the continuation." 
Further, "the use of plastics lead to pollution of soil and water as harmful chemicals from plastics seep into soil and kill microbial organisms. Plastics debris also disrupt water absorption process in soil and decrease the fertility of soil. On top of that, wastes dumped into rivers leads to the silting and clogging of rivers, which are the factors causing flood" [12].

From the above discussion, it is evident that plastic pollution is the most pressing environmental issue as it pollutes land and seawater. The use of biodegradable plastics is not a total solution as these materials are not fully decomposed, and instead turn into debris, thus contaminating the soil. Plastics also bring harm to the ocean and the organisms living in the area. Environmental degradation further causes the unfulfillment of human rights. Human rights are something that must be fulfilled for all people [12]. In other words, environmental issues are something that requires immediate solutions.

Several explanations above signify that plastics are inseparable from the modern lifestyle. One should note that the use of plastics can bring harm to the environment if there are no regulations concerning the utilization and management of this material. By that, restricting the use of plastics, specifically single-use plastics, is central to the efforts in minimizing wastes. This notion demands a particular strategy to ensure the effectiveness of the restriction of plastic. One of the examples is to get all people and government to be involved in the management of plastic waste.

\subsection{Development of plastic waste for ensuring sustainability: A policy}

Plastic waste is an issue that needs specific treatment. Government of Pohuwato regency, Gorontalo province, has continuously made several efforts to cut down plastics, as seen in the stipulation of Regional Regulation Number 3 of 2016 Concerning Waste Management and Regent Regulation Number 77 of 2018 Concerning Regional Policies and Strategies in Management of Household Waste. The regulation stipulated by the regional government is the follow-up of the Regional Strategy Policy (Kebijakan Strategi Daerah or Jakstrada) on the management of household waste up to $30 \%$ and the like and garbage handling by $70 \%$ to actualize free waste area in 2025.

According to the regulation, waste management is a systematical, comprehensive, and continuous activity, including waste reduction and waste handling (Article 1, point 6). This regulation mentions two policies and strategies in waste management, i.e., reduction and handling (Article 5). An important point to note is that the management has to be started with the reduction of waste, such as restriction of plastics, disposal of plastic waste to the area, production of plastics, and gradual management program. The policy has been taken into effect starting from 2019. Several programs of the policy include exchanging waste for basic foods and daily needs. People can exchange their plastic waste for food and other essentials. The collected garbage is priced based on the weight of the trash. In other words, the number of food or needs that they receive varies from one to another.

Based on the observation, one kilogram of mineral water glass is valued IDR 2600, while the price for a kilogram of colored plastic glass, oil lubricant bottle is IDR 2100 . One $1500 \mathrm{ml}$ mineral water bottle is priced at IDR 300 , and seven bottles of $600 \mathrm{ml}$ mineral water are priced at IDR 1000. Although the implementation of the program is yet reached other areas, it is expected that this idea becomes the first step to reduce the number of plastic garbage. Table 1 provides the data of the total production of waste by the unit of integrated waste management.

Table 1. Production of plastic waste in UPST Madani Teratai in 2019

\begin{tabular}{|c|c|c|c|c|c|c|c|c|}
\hline Month & $\begin{array}{c}\text { Plastic } \\
\text { Bottle }\end{array}$ & $\begin{array}{c}\text { Plastic } \\
\text { Glass }\end{array}$ & $\begin{array}{c}\text { Colored } \\
\text { Glass }\end{array}$ & $\begin{array}{c}\text { Lubricant } \\
\text { Bottle }\end{array}$ & $\begin{array}{c}\text { Glass/Bottle } \\
\text { Debris } \\
\text { (PP COLORS) }\end{array}$ & $\begin{array}{c}\text { Colored } \\
\text { Plastic } \\
\text { Bottle }\end{array}$ & $\begin{array}{c}\text { Total/ } \\
\text { Kg }\end{array}$ & $\begin{array}{c}\text { Total/Ton } \\
\text { March }\end{array}$ \\
\hline April & 98 & 41.2 & 27.4 & 37.7 & 16.3 & & 210.6 & 0.0063 \\
\hline May & 267.3 & 437.3 & 391.6 & 213.2 & 378.8 & & 1520.5 & 0.0460 \\
\hline July & 1114.3 & 278.2 & 197.1 & 436.2 & - & & 2025.8 & 0.0613 \\
\hline August & 1193.5 & 448.9 & 270.7 & 289.7 & 308.2 & & 2511 & 0.0760 \\
\hline September & 80.5 & 33.8 & 12.2 & 4 & 20.2 & & 150.7 & 0.0045 \\
\hline October & 2047.2 & 1177 & 642.6 & 465.3 & 658.2 & 76 & 5066.3 & 15.35 \\
\hline November & 1517.5 & 550.6 & 750 & 404.3 & 362.5 & & 3584.9 & 0.108 \\
\hline December & 1993.7 & 736.7 & 930.5 & 378.4 & 718.4 & & 4757.7 & 0.144 \\
\hline
\end{tabular}

Secondary data, 2019 
It should be noted that the above data do not represent all plastic wastes in the research site. Some garbage can be found in coastal areas. Old habits of burning garbage are also hard to break. Another constraint of the program is limited facilities and accesses to waste management. It is expected that the waste management program in the regency can minimize the number of plastic garbage in the area, considering the continuous increase in population growth by $1.99 \%$. Total waste production a day in 2020 is estimated at around 7.8 tons; this involves organic and inorganic waste. A rise in waste production urges immediate solutions. This condition implies that not all waste is gone through the recycling process, by which it needs integrated waste management with the involvement of related stakeholders, including people as they are central to the implementation of the program that has been designed by the government.

According to the data seen in the memorandum of the sanitation program (MPS) of the regency in 2015, 95.1\% of the residents have yet to implement waste sorting. One of the causes is the absence of a social development program. The participation of people is not that significant if it is compared with the needs for waste management in the area. The regional government has set the target for actualizing a clean and healthy environment through the improvement of a waste management program to $80 \%$ from the previous goal $35 \%$ by 2019 . This is done by reducing garbage heap and waste postcollection up to 50-meter cubic a day. A program wellknown as $3 \mathrm{R}$ has also been implemented in households to boost the involvement of society.

However, not all people have contributed to the program. Of the crucial aspects of a sustainable waste management program is the preservation of the environment. That being said, the success of the management is determined by the cooperation involving policy implementers and society to follow the regulation as the basis of waste management. Further development of waste reduction and management can be done by taken into consideration several aspects, such as the society, regional affordability, funding, and alternatives of plasticbased products, despite the economic potentials of plastics if it is well-utilized. These are of significance to the regional government policy in the actualization of sustainable and economical waste management. Some compelling points of the waste management program are:

1. Promoting people's awareness of the importance of plastic waste issues

2. Bringing changes to the habit of burning garbage, which has been practiced by many.

3. Building a law-obeying society.

4. Promoting the economic values of products that have been deemed of no use.

5. Improving the roles and engagement of society to support the government in minimizing plastic waste issues.

6. Waste reduction.

7. Keeping the environment free from plastic waste.

8. Improving the health quality of people.

9. Reducing and minimizing the use of plastics, especially single-use plastics.
10. Starting waste management program from the smallest unit in society, i.e., household.

11. Changing the perspective of people by improving the economic values of garbage.

12. Promoting sustainable environmental preservation.

Sustainable environmental preservation should start from oneself by doing something small, such as limiting the use of plastic. People can bring their plastic bags if they are going to a market and bring their tumblers as an alternative to using a single-use bottle. The environment will benefit much from these small acts if these are implemented on a massive scale. It is also essential to bring changes to the old waste management program and ensure the sustainability of the program.

\section{Conclusion}

Sustainable environmental preservation should start from oneself by doing something small, such as limiting the use of plastic. People can bring their plastic bags if they are going to a market and bring their tumblers as an alternative to using a single-use bottle. The environment will benefit much from these small acts if these are implemented on a massive scale. It is also essential to bring changes to the old waste management program and ensure the sustainability of the program.

\section{Recommendation}

A collaboration involving related stakeholders, specifically society, is required to ensure the success of the waste management program. In addition, limiting the use and production of plastics, especially for single-use plastics, is needed to curb the increase in the volume of plastic waste.

Acknowledge. We thank the Ministry of Research and Technology/ BRIN, National Agency for Research and Innovation for the financial support to fund this study. We also extend our gratitude to LPPM of Gorontalo State University and for those who had facilitated us in the data collection process.

\section{References}

1. World Bank Document. http://documents.worldbank.org/curated/en/6427515 27664372193/pdf/126686-INDONESIA-29-5-201814-34-5-SynthesisFullReportAPRILIND.pdf

2. J. R. Jambeck, et al. Sciencemag, 347, 6223 (2015)

3. P. Purwaningrum. JTL 8, 2 (2016)

4. Isnawaty. JKL 11, 2 (2014)

5. Dinas Lingkungan Hidup dan Kehutanan Provinsi Gorontalo tahun 2019

6. M. Tuli, et al. MF 6, 2 (2015)

7. M. R. Siombo. JH 18, 3 (2011)

8. S. Akhmaddhian. JDH 13, 3 (2013)

9. B. Lewis. MJICEL 8, 1 (2012)

10. D. Shelton. Research Handbook on International Environmental Law (2011) 
11. M. Fitzmaurice, D. Ong, P. Merkouris, D. Shelton (ed). RHIEL. 265 (2011)

12. P. Purwaningrum. IJUET 8, 2 (2016) 